\title{
FLOWERING AND FRUIT SET OF SIX CULTIVARS OF HIGHBUSH BLUEBERRY (Vaccinium corymbosum L.) IN THE CONDITIONS OF THE LUBLIN REGION
}

\author{
Małgorzata Bożek \\ Department of Botany, University of Life Sciences in Lublin, 20-950 Lublin. Akademicka 15, Poland \\ e-mail: malgorzata.bozek@up.lublin.pl
}

Received: 22.01.2009

\begin{abstract}
The results presented in this paper relate to the time and duration of flowering of highbush blueberry as well as fruit set in the conditions of flower isolation and free visitation by pollinating insects. Observations were carried out in the years 20012004 at a plantation located in Niemce near the city of Lublin. Six cultivars: 'Bluecrop', 'Bluejay', 'Croatan', 'Darrow', 'Northland' and 'Spartan', were covered by the study. The flowering period of the studied highbush blueberry cultivars was in May in three years of study, whereas in 2004 in May and June. Depending on the year, it lasted from 14 up to 21 days, on the average. Significant differences were found in the life span of a single flower which, depending on the cultivar and conditions prevailing during flowering, bloomed from 5 up to 10 days (the average for all the years for all the cultivars). With free access of pollinating insects, highbush blueberry set an average of 92 false-berries per 100 flowers, whereas only 40 during spontaneous self-pollination under the isolating cover. In each year of study, irrespective of atmospheric conditions prevailing during flowering as well as the time and duration of flowering, fruit set of the investigated cultivars in flowers freely accessible to pollinating insects should be considered to be good or very good.
\end{abstract}

Key words: blueberry, flowering, life span, pollination, fruit set

\section{INTRODUCTION}

In Poland the flowering of highbush blueberry starts earliest in the middle of May and it usually lasts 3-4 weeks (J a błoński et al. 1983; W ach and $\mathrm{K}$ ę s i k, 1997). A condition for obtaining good yields from these plants is that at least $80 \%$ of flowers set fruit, whereas other plants require fruit set from only $20 \%$ of flowers (Shutak and Marucci, 1966). Additionally, for good fruit yield, highbush blueberry requires flower visitation by pollinating insects, whose composition and number have an influence on the pollination effect ( $\mathrm{J}$ a b ł on s s i et al. 1983, M a c K e n - zi e, 1997; B i e n i a r z, 2007). Highbush blueberry is to a large degree self-fertile, however, in many cultivars a beneficial effect of cross-pollination on the size and quality of yield has been found ( $\mathrm{L} \mathrm{ang}$ and D a n ka, 1991; Hu ang et al. 1997; Eh lenfeld t, 2001).

In the present study, flowering time and duration, flower life span and fruit set in the conditions of free visitation of flowers by insects and without access of pollinators were compared for six cultivars of highbush blueberry (Vaccinium corymbosum L.) in the conditions of south-eastern Poland.

\section{MATERIALS AND METHODS}

The study conducted in the years 2001-2004 at a plantation of highbush blueberry (Vaccinium corymbosum L.) in Niemce near the city of Lublin related to six cultivars: 'Bluejay', 'Bluecrop', 'Croatan', 'Darrow', 'Northland' and 'Spartan'. The plantation with an area of 0.25 ha was established in spring 1993 on podzolic soil formed from light loamy sand, characterised by an acidic $\mathrm{pH}\left(\mathrm{PH}_{\mathrm{KCL}}=5.1\right.$ as well as low humus $(1.2 \%)$ and nutrient content. In order to improve the soil structure and to increase the humus content, coniferous sawdust compost was placed in the earlier ploughed furrows and mixed with the soil. 2-year-old trees were the planting material; they were planted at a spacing of $2 \mathrm{~m} \times 1 \mathrm{~m}\left(5000\right.$ pcs. $\times$ ha $\left.^{-1}\right)$. After planting, the shrub rows were mulched with a $5 \mathrm{~cm}$ sawdust layer and T-Tape system drip lines were installed. In the first year, natural sodding was allowed in the interrows, with grass cut several times during the growing period, when needed.

The duration and time of flowering of the studied cultivars were determined. The life span of flowers and some details of their flowering biology were observed in the years 2002-2004. For this purpose, 
10 buds were marked with coloured threads in the morning, shortly before opening, for ten consecutive days. On the next days, changes taking place in these flowers were observed: growth of the style, pollination process, corolla senescence and abscission.

In order to check the level of fruit set, in the years 2001-2004 two stems, on which flowers were counted, were designated on eight shrubs of each cultivar. A chiffon isolating cover was placed on one stem for the time of flowering, while the other one remained freely accessible to insects visiting the flowers. During maturation, developed fruits were counted and then their percentage relative to the number of flowers was determined.

The results were statistically processed using variance analysis and Duncan's test at $\alpha=0.05$.

\section{RESULTS}

The time of flowering of the studied highbush blueberry cultivars was in May in all the years of study, and only in 2004 it extended until the first decade of June (Fig. 1). In the year 2002, which was characterised by very early spring and average temperatures of the first four months much exceeding long-term norms, the plants started flowering earliest (30 April). The differences in the time of flowering onset between particular years for the respective cultivars were from 6 up to 14 days. The cultivars flowered for the shortest time in 2002 (an average of 14.2 days for the cultivars), when there was warm, sunny and rainless weather at the time of flowering. The month of May in 2003 turned out to be exceptionally warm and, in spite of rainfall above the long-term mean which occurred during the flowering of the investigated cultivars (8 May - 28 May), only slightly prolonged flowering of these plants was recorded (on the average 16.2 days). But cool and cloudy weather with rainfall in May in 2004 resulted in a significant extension of flowering of the shrubs (on the average up to 24.7 days). Among the studied cultivars, the shrubs of 'Northland' flowered the shortest, on the average 16.2 days over the four years of study, and 'Spartan' the longest - 20.5 days.

A significant effect of the cultivar and atmospheric conditions prevailing during flowering on the flower life span was found (Tab. 1). The lifetime of a single flower over the period of three years for the six cultivars was from 3 up to even 13 days. The least advantageous conditions for flowering occurred in May 2004, which resulted in a significant extension of the flower lifetime up to an average of 9.8 days in the case of all the cultivars. But the average flower life span for these cultivars in the years 2002 and 2003 was within a range of 5-6 days. The flowers of the cultivars 'Bluecrop', 'Northland' and 'Darrow' lived the shortest, with an average of about 6 days over the three years of study, whereas 'Spartan' and 'Croatan' the longest - about 8 days.

Table 1

Longevity of one flower of six cultivars of highbush blueberry (Vaccinium corymbosum L.) in the years 2002-2004.

\begin{tabular}{|c|c|c|c|c|c|}
\hline \multirow{2}{*}{ cultivars } & \multicolumn{5}{|c|}{ Life span per one flower (days)* } \\
\hline & & 2002 & 2003 & 2004 & mean \\
\hline \multirow{2}{*}{ Bluecrop } & $\min -\max$ & $4-6$ & $3-7$ & 8-9 & 3-9 \\
\hline & mean & $5.0^{\mathrm{a}}$ & $4.9^{\mathrm{a}}$ & $8.2^{\mathrm{b}}$ & $6.0^{\mathrm{A}}$ \\
\hline \multirow{2}{*}{ Bluejay } & $\min -\max$ & $4-6$ & $4-9$ & $9-10$ & $4-10$ \\
\hline & mean & $5.5^{\mathrm{a}}$ & $5.7^{\mathrm{a}}$ & $9.9^{\mathrm{b}}$ & $7.0^{\mathrm{B}}$ \\
\hline \multirow{2}{*}{ Croatan } & $\min -\max$ & $6-8$ & $4-9$ & $10-11$ & $4-11$ \\
\hline & mean & $7.1^{\mathrm{a}}$ & $6.9^{\mathrm{a}}$ & $10.9^{\mathrm{b}}$ & $8.3^{\mathrm{C}}$ \\
\hline \multirow{2}{*}{ Darrow } & $\min -\max$ & $4-5$ & $5-7$ & $8-10$ & $4-10$ \\
\hline & mean & $4.5^{\mathrm{a}}$ & $5.9^{\mathrm{b}}$ & $9.2^{\mathrm{c}}$ & $6.5^{\mathrm{A}}$ \\
\hline \multirow{2}{*}{ Northland } & $\min -\max$ & $3-5$ & 4-7 & $7-11$ & $3-11$ \\
\hline & mean & $3.9^{\mathrm{a}}$ & $5.7^{\mathrm{b}}$ & $9.0^{c}$ & $6.2^{\mathrm{A}}$ \\
\hline \multirow{2}{*}{ Spartan } & $\min -\max$ & $5-8$ & $4-10$ & $11-13$ & $4-13$ \\
\hline & mean & $6.2^{\mathrm{a}}$ & $6.3^{\mathrm{a}}$ & $11.8^{\mathrm{b}}$ & $8.1^{\mathrm{C}}$ \\
\hline \multirow{2}{*}{ Mean for cultivars } & $\min -\max$ & $4-9$ & $3-10$ & $7-13$ & $3-13$ \\
\hline & mean & $5.4^{\mathrm{A}}$ & $5.9^{\mathrm{B}}$ & $9.8^{\mathrm{C}}$ & 7.0 \\
\hline
\end{tabular}

* mean followed by the same letter are not significantly different at $\alpha=0.05$ 


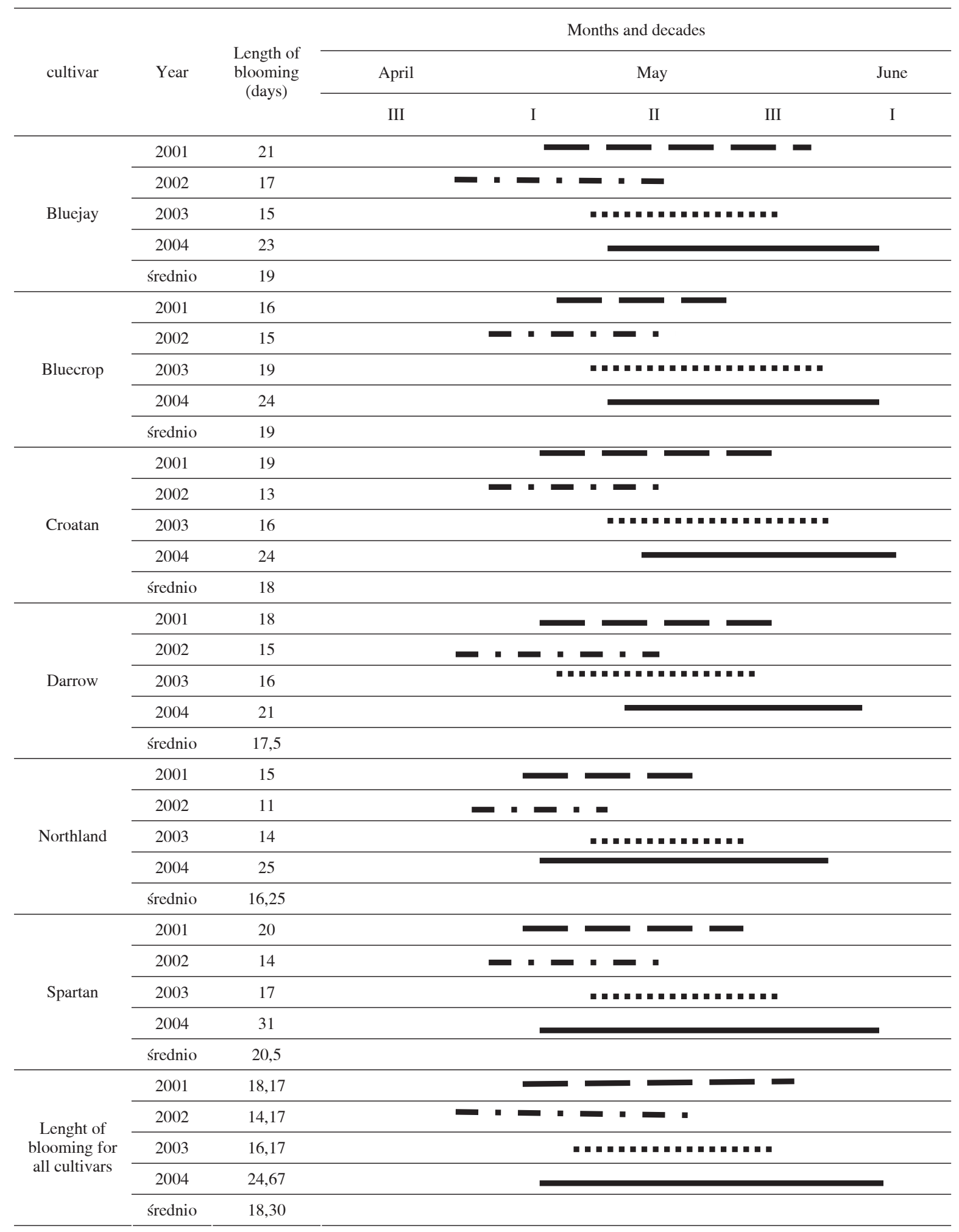

Fig. 1. The period and lenght of blooming of six cultivars of highbush blueberry (Vaccinium corymbosum L.) in Lublinie in the years 2001-2004. 
Table 2

Setting of fruit of highbush blueberry (Vaccinium corymbosum L.) cultivated in the Lublin conditions region (2001-2004).

\begin{tabular}{|c|c|c|c|c|c|c|c|c|c|c|}
\hline \multirow{3}{*}{ cultivar } & \multicolumn{10}{|c|}{ Percentage of flowers setting fruit* } \\
\hline & \multicolumn{5}{|c|}{ non isolated } & \multicolumn{5}{|c|}{ isolated } \\
\hline & 2001 & 2002 & 2003 & 2004 & mean & 2001 & 2002 & 2003 & 2004 & mean \\
\hline Bluejay & $78.9^{\mathrm{ab}}$ & $81.9^{\mathrm{a}-\mathrm{c}}$ & $88.7^{\mathrm{a}-\mathrm{d}}$ & $87.4^{\mathrm{a}-\mathrm{d}}$ & $84.2^{\mathrm{A}}$ & $38.2^{\mathrm{a}-\mathrm{g}}$ & $19.0^{\mathrm{a}-\mathrm{c}}$ & $37.3^{\mathrm{a}-\mathrm{g}}$ & $15.0^{\mathrm{a}}$ & $27.4^{\mathrm{A}}$ \\
\hline Bluecrop & $93.8^{\mathrm{cd}}$ & $95.1^{\mathrm{cd}}$ & $93.9^{\mathrm{cd}}$ & $95.9^{\mathrm{cd}}$ & $94.7^{\mathrm{B}}$ & $39.7^{\mathrm{ab}}$ & $31.5^{\mathrm{a-f}}$ & $64.2^{\mathrm{h}}$ & $57.2^{\mathrm{gh}}$ & $48.2^{\mathrm{B}}$ \\
\hline Croatan & $92.9^{b-d}$ & $96.2^{\mathrm{cd}}$ & $94.1^{\mathrm{cd}}$ & $98.8^{\mathrm{d}}$ & $95.5^{\mathrm{B}}$ & $30.4^{\mathrm{a}-\mathrm{c}}$ & $47.5^{\mathrm{e}-\mathrm{h}}$ & $55.1^{\mathrm{f}-\mathrm{h}}$ & $42.2^{\mathrm{c}-\mathrm{h}}$ & $43.8^{\mathrm{B}}$ \\
\hline Darrow & $96.9^{\mathrm{cd}}$ & $84.0^{\mathrm{a}-\mathrm{d}}$ & $97.0^{\mathrm{cd}}$ & $97.1^{\mathrm{d}}$ & $93.8^{\mathrm{B}}$ & $40.7^{\mathrm{b}-\mathrm{h}}$ & $41.0^{\mathrm{a}-\mathrm{h}}$ & $54.5^{\mathrm{e}-\mathrm{h}}$ & $36.8^{\mathrm{a}-\mathrm{g}}$ & $43.3^{\mathrm{B}}$ \\
\hline Northland & $76.1^{\mathrm{a}}$ & $97.7^{\mathrm{d}}$ & $86.5^{\mathrm{a}-\mathrm{d}}$ & $96.9^{\text {cd }}$ & $89.3^{\mathrm{AB}}$ & $21.6^{\mathrm{a}-\mathrm{d}}$ & $42.0^{\mathrm{c}-\mathrm{h}}$ & $32.6^{\mathrm{a}-\mathrm{g}}$ & $17.0^{\mathrm{ab}}$ & $28.3^{\mathrm{A}}$ \\
\hline Spartan & $91.9^{\mathrm{b}-\mathrm{d}}$ & $94.0^{\mathrm{cd}}$ & $90.8^{\mathrm{b}-\mathrm{d}}$ & $93.2^{\mathrm{b}-\mathrm{d}}$ & $92.5^{\mathrm{B}}$ & $43.5^{\mathrm{d}-\mathrm{h}}$ & $47.6^{\mathrm{e}-\mathrm{h}}$ & $47.5^{\mathrm{e}-\mathrm{h}}$ & $55.9^{\mathrm{f}-\mathrm{h}}$ & $48.6^{\mathrm{B}}$ \\
\hline mean & $88.4^{\mathrm{a}}$ & $91.5^{\mathrm{ab}}$ & $91.9^{\mathrm{ab}}$ & $94.9^{\mathrm{b}}$ & $91.7^{\mathrm{Y}}$ & $35.7^{\mathrm{a}}$ & $38.1^{\mathrm{a}}$ & $48.5^{\mathrm{b}}$ & $37.3^{\mathrm{a}}$ & $39.9^{x}$ \\
\hline
\end{tabular}

* mean followed by the same letter are not significantly different at $\alpha=0.05$

A significant effect of the cultivar, study year and pollination mode on fruit set of highbush blueberry was found (Tab. 2). In the conditions of free access of pollinating insects, fruits were obtained from, on the average, almost $92 \%$ of flowers for all the cultivars, and during the isolation of flowers only from approx. $40 \%$. Every year, the cultivars 'Croatan' and 'Bluecrop' set the largest amount of fruit from flowers visited by pollinating insects (approx. 95\%), whereas the smallest amount was obtained from 'Bluejay' (84\%). During the isolation of flowers, the cultivars 'Bluejay' $(27.36 \%)$ and 'Northland' (28.30\%) also had the poorest fruit set, whereas 'Spartan' and 'Bluecrop' had the best rate (approx. 48\%).

It was found that a significant extension of the flowering period and flower life span in 2004, caused by cool and cloudy weather during flowering, did not reduce the level of fruit set from flowers with free access for pollinating insects, and even an increase in fruit set per 100 flowers was noted (Fig. 1, Tab. 1, Tab. 2).

\section{DISCUSSION}

The flowering of the studied highbush blueberry cultivars was strictly dependent on atmospheric conditions. Cool, cloudy and wet weather slowed down the bud-opening process and clearly extended the flowering, whereas warm, sunny and dry weather accelerated and shortened it. It is in complete agreement with the observations of other authors who draw attention to the modifying effect of weather factors in the plant flow- ering process (Jabłoński and $\mathrm{Szk}$ lanowska, 1997).

Highbush blueberry flowers, without detriment to fruit set, extend the flowering during adverse weather conditions which strongly affect both the course of flowering processes and flower visitation by pollinating insects. It is a very beneficial feature, also observed in the case of other plant species requiring the presence of pollinating insects for effective pollination $(\mathrm{E} \mathrm{u} \mathrm{c} \mathrm{k} \mathrm{a}$ et al. 1972; Jabłoński and Szklanowska, 1997; K o ł t o w s ki et. al. 1998).

The results relating to the percentage of flowers setting fruit obtained in the present study are similar to the data of J abłońs ki et al. (1983) and W a ch (2004) regarding free pollination of highbush blueberry, but they are definitely higher during flower isolation as compared to the data of $\mathrm{J} a b ł o$ ń $\mathrm{ski}$ et al. (1983). On the other hand, B i e n i a r z (2007), studying four cultivars in the conditions of southern Poland, recorded poorer fruit set, ranging $41-78 \%$, in the conditions of free pollination of flowers of this species, but similar results (28-52\%) during isolation. Free access of insects had a beneficial effect on fruit set of all the studied cultivars, which confirms the need to provide pollinators at plantations of the cultivar Vaccinium corymbosum. The different percentages of fruit set in the conditions of flower isolation obtained in the presented experiment may prove a higher degree (except self-fertility and parthenocarpy) of self-pollination, of some cultivars relative to others. At the time of the reduction in population size of pollinators, these cultivars 
may give better yields. In the absence of pollinating insects, the cultivar 'Spartan' set fruit by far the best, irrespective of weather conditions. A high level of fruit set in the conditions of spontaneous self-pollination under the isolating cover was also obtained in the case of 'Bluecrop', 'Croatan' and 'Darrow'. However, distinct differences in pollination effectiveness occurred in these cultivars between particular years, probably attributable to atmospheric factors. The other two cultivars, 'Bluejay' and 'Nothland', proved to be varieties with a low level of fruit set during flower isolation, which indicates that the presence of pollinators is particularly necessary for good yielding. Such cultivarspecific traits relating to different degrees of self-pollination and self-fertility are known among other plant species (D e n is o w, 2003).

The percentage of fruit set from non-isolated flowers in the conditions of the present study at a level of $91.6 \%$ (an average for the cultivars) should be considered to be very good, guaranteeing that high commercial yields will be obtained. J a błońs ki et al. (1983) report that better fruit set of highbush blueberry took place when there was lower temperature and higher air humidity at the time of flowering, which was also confirmed in the present study in 2004 .

\section{CONCLUSIONS}

In each year of study, irrespective of atmospheric conditions prevailing during flowering as well as flowering time and duration, fruit set of the investigated cultivars in flowers freely accessible to pollinating insects should be considered to be good or very good.

Fruit set in the case of free pollination was significantly higher, by an average of over $50 \%$ for the studied cultivars, than that of isolated flowers.

The flowering duration of the shrubs and the flower life span extend significantly when there is cool, wet weather during flowering, but it does not result in a reduction in the percentage of fruit set per 100 flowers.

\section{REFERENCES}

Bieniarz M., 2007. Effects of open and self pollination of four cultivars of highbush blueberry (Vaccinium corymbosum L.) on flower fertilization, fruit set and seed formation. J. Fruit Ornam. Plant Res. 15: 35-40.

De n is ow B., 2003. Self-pollination and self-fertility in eight cultivars of black currant (Ribes nigrum L.). Acta Biol. Crac. Ser. Botanica, 45 (1): 111-114.

Ehlenfeldt M. K., 2001. Self- and cross-fertility in recently released highbush blueberry cultivars. Hort. Sci. 36: 133-135.
Huang Y. H., Lang G. A., Johnson C. E., Sundberg M. D., 1997. Influences of cross- and self-pollination on peroxidase activities, isozymes, and histological localization during 'Sharpblue' blueberry fruit development. J. Amer. Soc. Hort. Sci. 122 (5): 616-624.

Jabłoński B., Król S., Pliszka K., Żurowska Z., 1983 Nektarowanie i zapylanie borówki wysokiej (Vaccinium corymbosum L.). / Nectar secretion and pollination of highbush blueberry (Vaccinium corymbosum). Pszczeln. Zesz. Nauk. XXVII: 91-109.

Jabłoński B., Szklanowska K., 1997. Wpływ niektórych czynników pogody na kwitnienie, nektarowanie, pylenie i oblot przez owady zapylające entomofilnych roślin uprawnych. / The influence of certain weather factors on blooming, nectar secretion, pollen production and insect visitation of entomophilous cultivated plants. I Ogólnopolska Konferencja Naukowa pt. „Biologia kwitnienia, Nektarowania i Zapylania Roślin”, 13-14 Listopada, Lublin: 52-58.

Kołtowski Z., Jabłoński B., Szk lanowska K., 1998. Wpływ pogody na kwitnienie i oblot przez owady zapylające porzeczki czarnej (Ribes nigrum L.). / The influence of weather on flowering of black currant (Ribes nigrum L.) and foraging by pollinating insects. Pszczeln. Zesz. Nauk. 42 (1): 253-254.

L a n g G. A., D a n k a R. G., 1991. Honey-bee-mediated crossversus self-pollination of ,Sharpblue' blueberry increases fruit size and hastens ripening. J. Amer. Soc. Hort. Sci. 116: 770-773.

Łucka M., Lech W., Dorosińska K., 1972. Przebieg procesu zapylania i badanie stopnia samopylności u porzeczki czarnej. / The pollination process and study of the degree of self-pollination in Ribes nigrum. Zesz. Nauk. WSR Kraków, 70 (2): 89-101.

Mackenzie K., 1997. Pollination requirements of three highbush blueberry (Vaccinium corymbosum) cultivars. J. Amer. Soc. Hort. Sci. 122 (6): 891-896.

Shutak V. G., Marucci P. E., 1966. Blueberry culture. [In:] Plant and fruit development. Eck P., Childers N.F. (eds.), Rutgers Univ. Press. New Brunswick, NJ: 179198.

Wach D., Kęsik T., 1997. Kwitnienie i zawiązywanie się owoców borówki wysokiej uprawianej na Lubelszczyźnie w latach 1996-1997. / Flowering and fruit set of highbush blueberry cultivated in Lublin region in the years 1996-1997. I Ogólnopolska Konferencja Naukowa pt. „Biologia kwitnienia, Nektarowania i Zapylania Roślin”, 13-14 Listopada, Lublin: 125-129.

Wa ch D., 2004. Charakterystyka zawiązywania owoców borówki wysokiej (Vaccinium corymbosum L.) w warunkach Lubelszczyzny na tle wybranych odmian. / Characterization of fruit set of highbush blueberry ( Vaccinium corymbosum L.) in the Lublin region conditions against the background of selected cultivars. Ann. Univ. Mariae Curie-Słodowska, Sect. EEE, XIV: 1-6. 
Kwitnienie i wiązanie owoców sześciu odmian borówki wysokiej (Vaccinium corymbosum $\mathbf{L}$.) w warunkach Lubelszczyzny

\section{Streszczenie}

Wyniki przedstawione w niniejszej pracy dotyczą pory i długości kwitnienia borówki wysokiej oraz wiązania owoców w warunkach izolowania kwiatów i w czasie swobodnego oblotu przez owady zapylające. Obserwacje prowadzono w latach 2001-2004 na plantacji położonej w Niemcach k/Lublina. Badaniami objęto sześć odmian: 'Bluecrop', 'Bluejay', 'Croatan', 'Darrow', 'Northland' i 'Spartan'. Okres kwitnienia badanych odmian borówki wysokiej przypadał w trzech latach badań w maju, a w 2004 w maju i czerwcu. W zależności od roku średnio wynosił od 14 dni do 24 dni. Stwierdzono istotne różnice dotyczące długości życia pojedynczego kwiatu, które w zależności od odmiany i warunków panujących podczas kwitnienia kwitly od 5 do 10 dni (średnio z lat dla wszystkich odmian). Przy swobodnym dostępie owadów zapylających borówka wysoka zawiązywała średnio 92 nibyjagody ze 100 kwiatów, natomiast podczas izolowania tylko 40. W każdym roku badań, niezależnie od warunków atmosferycznych panujących podczas kwitnienia, pory i długości kwitnienia, wiązanie owoców badanych odmian z kwiatów swobodnie dostępnych dla owadów zapylających należy uznać za dobre lub bardzo dobre. 